\title{
Banyumas as a Part of Southeast Asian Maritime World: A Study of the Readiness of the Regency to Deal with the ASEAN Economic Community
}

\author{
Dr. Ely Triasih Rahayu, S.S., M. Hum \\ Renny Miryanti, S.IP., M.Si \\ Tundjung Linggarwati, S.IP., M.Si
}

\begin{abstract}
This study is conducted upon 27 village leaders in two sub-districts of Banyumas (Wangon and Ajibarang) as the areas of investment development plan in Banyumas, Central Java, Indonesia. The purposes of this study are: (1) to figure out the understanding of heads of the villages in Banyumas related to the leadership issues, especially on global insight leadership, (2) to know the preparation of village leaders to face the AEC, and (3) to create global insight leadership model that may become input for policy makers in Banyumas. Data are obtained through in-depth interviews with the informants or respondents by having an intensive and close relationship. Data are collected by having in-depth interviews to create openness and focus group discussion (FGD). The results of this study show that: (1) heads of the villages mostly had organizational experience that might be used to understand the leadership patterns, (2) the respondents also had basic understanding on local issues and new regulations related to village governance, for instance Village Acts that they obtained from socializations and trainings conducted by the local governments and other sources of information, (3) understanding related to AEC was very poor and most of them stated that they had never involved in global interactions, (4) less competence of foreign language faced either by of the village leaders or officials, and lack of ability to access technology, and (5) there was no official dissemination from the local governments.
\end{abstract}

Keywords: ASEAN Economic Community; Banyumas; Village Leaders; Global Leadership; Village Acts

\section{INTRODUCTION}

The Regency of Banyumas occupies a strategic place in the larger Southeast Asian World. Located in the Southwestern corner of Central Java, The regency borders the Regency of Cilacap with its important part overlooking the Indian Ocean. The location of Banyumas that is very close to the harbor of Cilacap creates a good opportunity for the regency to play an important role in Southeast Asian Maritime World. International developments after World War II were characterized by the proliferating phenomena of regional agreements in various parts of the world regarding globalization. The data from WTO (World Trade Organization) published in Indonesian Economic Outlook of 2008-2014 of Bank Indonesia showed that there are 200 regional economic agreements all over the world that works effectively. Several more are still at the stage of negotiation. ${ }^{1}$

ASEAN countries agreed to realize the ASEAN Economic Community (AEC) in 2015 with the signing of ASEAN Declaration in Singapore on November 20 of 2007. This signing marked a new chapter in the history of ASEAN regional cooperation. ASEAN Economic Community means ASEAN transformation in which goods, services, and skilled labors may move freely without limits supported by the more freely capital movements. ${ }^{2}$

AEC was basically the extension of regional economic integration started several years ago at the formation of AFTA in 1992. The main framework of regional economic integration was then formulated in ASEAN Summit of 1997 in Kuala Lumpur which resulted in ASEAN VISION of 2020. It is the achievement of stable, prosperous, and highly competitive regions, with the balanced

\footnotetext{
${ }^{1}$ Outlook Ekonomi Indonesia 2008-2014: Integrasi Ekonomi ASEAN dan Prospek Perekonomian Nasional. Edisi IV, Januari 2008. Biro Riset Ekonomi - Direktorat Riset Ekonomi dan Kebijakan Moneter Bank Indonesia. ${ }^{2}$ Ibid
} 
economic growth, reduced poverty, and reduced socio-economic inequality. In the ASEAN Summit of January 2007, the acceleration of the AEC establishment by 2015 was then agreed. ${ }^{3}$

There are four currents of liberalization which may occur in the ASEAN regions due to the implementation of AEC of 2015. These include free flow of goods, services, investments, skilled labors (experts), and capitals. The free trade accelerations throughout ASEAN requires good preparation from all parties involved in all levels: nationally, regionally, and locally.

The Regency of Banyumas is an important part of the Republic of Indonesia. It will certainly get the impacts of the policies of the ASEAN countries in implementation of ASEAN Economic Community of 2015. Banyumas is located in Central Java, one of the main provinces in Indonesia. Banyumas needs to prepare itself for the global insight leadership, not only at the level of the regional but also in the villages. From the village, it may then be socialized up to the level of the community. Villages used to be the main center of community life in Indonesia. For Indonesian people, village is the beat of their lives.

The spirit of mutual cooperation of Indonesian society makes villages along with their officials lie the best communication instruments for each policy from national to regional levels. Good village leaders may influence how the village grows. Thus, village leaders understand rules related to the village and embrace global issues are extremely needed. This is even more so in the context of the ASEAN Economic Community. The policy of AEC formation should not become the policy of ivory tower, but to be the grounding policy. To readily face AEC, the Indonesian people should be well prepared from the lowest level of society, with all its instruments (RT, RW).

Three questions arise: First, how do the regional leaders understanding the implementation of free trade in the regional agreements of the ASEAN Economic Community. Second: how does leadership influence people's understanding of the EAC in Banyumas, particularly Ajibarang and Wangon subdistrict regarding the ASEAN Economic Community of 2015. The third question of this study is how can the government create global insight regional leadership model in Banyumas to face the ASEAN Economic Community.

\section{RESEARCH METHODOLOGY}

This research uses heads of the villages, heads of the sub-districts, and public figures from Sumpiuh and Tambak sub-district of Banyumas regency as the respondents and informants in order to identify the local leaders' knowledge and needs due to their readiness to face ASEAN free trades, especially to introduce their local products at the ASEAN markets. It is expected that through those informants, the researchers may obtain comprehensive data and information to be analyzed that an appropriate model may be well designed.

Data are obtained through in-depth interviews with the informants or respondents by having an intensive and close relationship. Data are collected by having: first, in-depth interviews to create openness; and second, focus group discussion (FGD) to figure out their understanding on a particular problem (Bungin, 2008 : 131). The research informants consist of first, heads of villages and heads of sub-districts as the primary respondents; second, local governments as the policy administrators; and third, the public figures.

\subsection{ASEAN Economic Community}

At the ASEAN Summit of 1997 in Kuala Lumpur, the ASEAN Vision of 2020 was announced. It is the achievement of stable, prosperous, and highly competitive regions with the balanced economic growth, reduced poverty, and reduced socio-economic inequality. At the ASEAN Summit of 2003 in Bali, 3 (three) pillars were established to realize the ASEAN vision: ASEAN Security Community (ASC), ASEAN Economic Community (AEC), and ASEAN Socio Cultural Community (ASCC). ${ }^{4}$ The idea of ASEAN Community itself was adopted from what happened in Europe with its European Union.

\footnotetext{
${ }^{3}$ Miryanti, Renny, "Peluang dan Tantangan dalam Membangun Masyarakat ASEAN 2015: Menengok ASEAN dan Uni Eropa", Jurnal Insignia, Vol.1. No.1.Tahun 2011

${ }^{4}$ Ibid
} 
The AEC has the blueprint drafts consisting of characteristics, elements, action plans of priorities, targets and achievement schedule of the AEC with four (4) pillars. They are: ${ }^{5}$

1) Single market and production base, including free flow of goods, services, investment, skilled labors, capitals, and the Priority Integration Sectors,

2) Competitive economic regions, including: competitive policy, consumer protection, Intellectual Property Rights (IPR), infrastructure development, energy, taxation, e-commerce,

3) Equitable economic development, including: SME development, initiative for ASEAN integration,

4) Full integration of global economy, including: coherent approach toward external economic relations, enhanced participation in global supply networks.

The ASEAN Summit in January of 2007 agreed that the establishment of AEC in 2020 was accelerated to 2015. All heads of ASEAN countries then finally approved and signed the AEC Blueprint drafts in ASEAN Summit of November 2007.

ASEAN free trade means the elimination of trade barriers between countries to establish more free markets among its members, including the reduction of admission charges on required goods, the elimination of quota restrictions and the other non-tariff barriers restricting the flow of the imported goods. Each country is allowed to set its own import admission charges which come from those nonASEAN countries. In various levels of preparation, Indonesia along with those five other members of ASEAN countries: Brunei Darussalam, the Philippines, Malaysia, Singapore and Thailand had been together in the implementation of ASEAN Free Trade Areas (AFTA) in the first phase starting in 2010. In the second phase starting in 2015, AFTA may include other members including Cambodia, Laos, Myanmar, and Vietnam. This is based on the economic growth and participation as the members of ASEAN recently inaugurated. ASEAN countries had done free trade areas with China for the ASEAN 6 (Indonesia, Malaysia, Singapore, Thailand, Philippines, and Brunei Darussalam) and by 2015 for Laos, Cambodia, Myanmar, and Vietnam. ${ }^{6}$

The four pillars achievement in AEC may be gradually undertaken, with the main focus on the first pillar achievement in creating trade liberalization on goods, services and investments. The first pillar achievement may become the basis of the other pillars that ASEAN may be completely ready for global economy integration. It is expected that Indonesia can eventually integrate with the global economy completely and shows its belief that regional cooperation of AEC is the "building block" leading to the multilateral free trade achievement. Regional cooperation undertaken may encourage the creation of comparative eminence for the areas as a whole that eventually improve opportunities of each country in global competition. In addition, regional cooperation undertaken by ASEAN is also open. Along with the reduction of admission charges and barriers among members of ASEAN countries (preferential liberalization), it is also applicable for all the countries in the world (unilateral liberalization). ${ }^{7}$

\subsection{Leadership Concepts}

Strong leadership determines the success of the organization success achievement. Northouse defines leadership as a process in which individual influences a group of individuals to achieve the common goals. ${ }^{8}$ Wirawan (2013) states that leadership reflects what is undertaken by the leaders in influencing their followers to realize the vision. ${ }^{9}$ Northouse (2013) states that leadership style includes someone's behavior pattern which is trying to influence others. ${ }^{10}$

\footnotetext{
${ }^{5}$ Ibid

${ }^{6}$ Ibid

7 Soesastro, Hadi, 2004. Kebijakan Persaingan, Daya Saing, Liberalisasi, Globalisasi, Regionalisasi, dan Semua Itu, CSIS Working Paper Series March 2004.

${ }^{8}$ Northouse, Peter G. 2013. Kepemimpinan: Teori dan Praktik. Edisi keenam.Diterjemahkan oleh Dr. Ati Cahayani. Jakarta: PT. Indeks dalam Intan Puspitasari dkk. 2014. "Analisis Gaya Kepemimpinan Lintas Budaya Ekspatriat (Studi Penelitian Pada Pt. Haier Sales Indonesia, Jakarta Utara)”. Jurnal Administrasi Bisnis (JAB) Vol. 8 No. 1 February 2014. Universitas Brawijaya. P.2

${ }^{9}$ Wirawan. 2013. Kepemimpinan : Teori, Psikologi, Perilaku Organisasi, Aplikasi dan Penelitian. Jakarta: PT.

RajaGrafindo Persada. P.351

${ }^{10}$ Puspitasai, Intan, Op.Cit.
} 
Gibson defines Leadership as an attempt to use a style to influence but not to force in motivating individuals to achieve the goals. Winardi states that leadership is a relationship where one person, the leader influences others to voluntarily cooperate in completing duties to achieve the desired goals. Leadership may happen in certain situations where someone influences other behaviors either individually or in groups. The success of a leader in influencing behavior is heavily influenced by the leadership style. There are two things that are usually undertaken by the leader to his subordinates or followers: the directing and supporting behaviors. ${ }^{11}$

\subsection{Leadership Theories and Styles}

Leadership theories discuss how a person becomes a leader or how a leader arises. The following are some examples: ${ }^{12}$

\section{Genetic Theory}

The essence of this theory is that "leaders are born and not made". Believers of this theory argue that a leader is born with talents of being a leader. At any condition, place, and time, the person will always become the leader as he or she was born for. It means that he or she has been destined to be the leader.

\section{Social Theory}

If genetic theory states that "leaders are born and not made", those who believe in suggest the opposite, "Leaders are made and not born". Believers of this theory argue that everyone may become a leader as long as education and opportunities are necessarily given.

\section{Ecological Theory}

This theory is the combination of genetic and social theories: This theory argues that someone may become a good leader as he or she was born with leadership talents and then was further improved through education and experiences.

According to Hersey and Blanchard, there are four types of leadership styles:

1) Directive Type is characterized by one-way communication. The leader limits the subordinate roles and showed them what, when, where and how one duty should be done. Problem solving and decision making are still his responsibility. They are conveyed to his subordinates but the executions are closely supervised.

2) Consultative Type is characterized by two-way communication. Supports are provided for the subordinates. The leader willingly listens to the subordinates' complaints and feelings upon the decision made. While the assistance to subordinates is improved, the leader executes the decision;

3) Participatory type is characterized by the presence of two controls over the leader and subordinates who are involved in problem solving and decision making; and

4) Discretionary type is characterized by the willingness of leader to discuss the problem.

This study uses qualitative method. It aims to understand or interpret certain phenomena according to the meanings perceived by people. I use perception approach in this study. In perception approach, someone may obtain a lot of information which then forms the image belief system regarding what has, is, and will happen (facts) and what image is supposed to happen (values). They will forms actions or decisions of the individual or group of people on a problem/issue/phenomenon.

Instinct and personality are the static aspects of an individual and perception or "image" of individual is dynamic because perception frequently changes. According to Kenneth Boulding, when we react to the world around us, we actually react to our image upon world. (Reference for building here)

People take actions based on what they "know". Someone's responses to something depend on how he defines it. Differences in behavior are related to the way people perceive "reality". ${ }^{13}$

The relationship between image, perception and action Bruce Russet and Harvey Star explain as follows: The first stage in a decision/attitude is the arising situation or problem. However, before the situation arises, there are three things happening. First, there must be some kind of stimulus or trigger from the environment called trigger event. Second, there must be attempts to perceive stimulus. It is a

\footnotetext{
${ }^{11}$ Handayani, Agustuti. Op Cit. Hal 85-86

${ }^{12}$ Ibid

${ }^{13}$ Mas'oed, Mohtar, 1989. Studi Hubungan Internasional: Tingkat Analisisi dan Teorisasi, PAU Studi Sosial UGM.Yogyakarta. Hal.19
} 
process that is applied by an individual to select, organize, and assess the incoming information upon the world around. Third, there must be attempts to interpret stimulus perceived while perception and interpretation greatly depend on image in mind of the decision maker. ${ }^{14}$

The figure below explains how someone's image influences his perception upon the world around: ${ }^{15}$

The relationship of belief system with perception, attitude and action

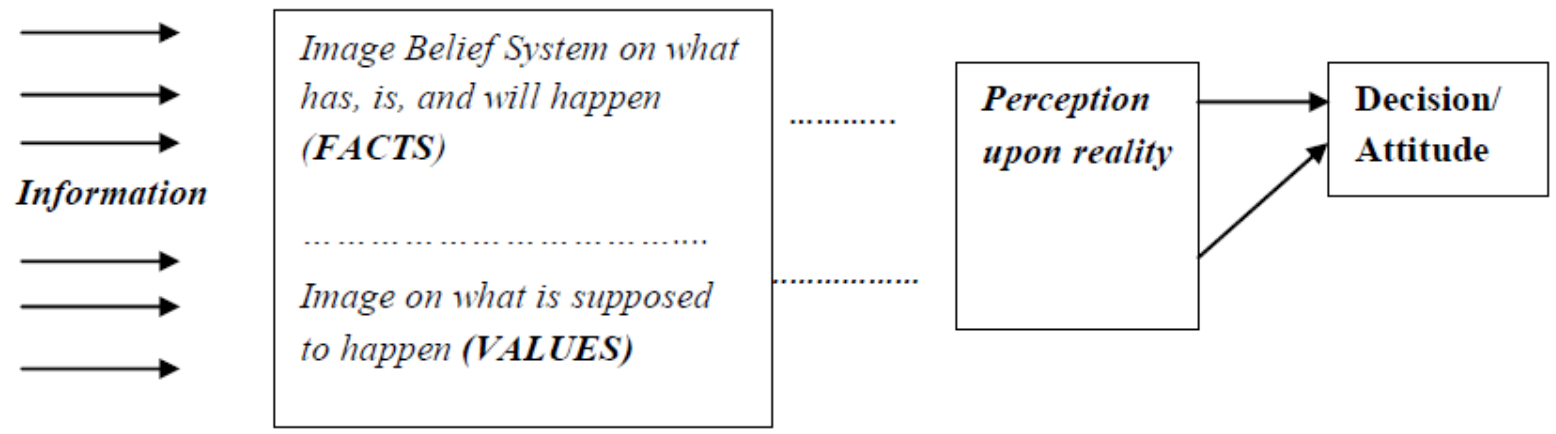

This study took place in 27 villages: 12 villages of Wangon sub-district and 15 villages of Ajibarang sub-district in Banyumas, Central Java and 27 village leaders as respondents.

Locations were selected because of the regional investment development plan by the Board of Investment and Licensing Services (BPMPP) of Banyumas district reinforced by the data obtained from the Central Bureau of Statistics in Banyumas of 2012. These locations were the fastest growing economic areas of Banyumas.

The purpose of this study is to see the preparedness of village leaders in Banyumas to face free trade that would be implemented immediately in the ASEAN Economic Community in all areas of ASEAN members. ASEAN Economic Community will liberalize four (4) community economic regions: free flow of goods, investment, skilled labors, and services.

More specifically, this study aims to (1) generate global insight leadership model as the efforts in preparing Banyumas to face the ASEAN Economic Community of 2015; (2) implement global insight leadership model. The results of this study are expected to provide:

1. Recommendations for policy makers in local governments so that villages may immediately prepare themselves to face ASEAN Economic Community of 2015. It is our hope that they have competitiveness in global competition at the regional level of ASEAN.

2. Understanding of various local elements, on how global insight leadership capital in globalization era with its free competitions in various economic levels. It is our hope that Banyumas people will not only become the viewers, but become ones of the international actors.

3. Preparation for the village leaders to embrace the ASEAN Economic Community of 2015.

\section{RESUltS AND DisCUSSIONS}

The survey showed that the 27 village leaders did not have a good understanding of the EAC. However, understanding upon local leadership and issues or rules, for example regarding to village acts was satisfactory.

Based on survey results, those 27 village leaders were all males. 60\%/16 village leaders were graduated from high school, four (14.8\%) earned bachelor degrees (S1). The survey showed that they had already had basic understanding of leadership obtained from trainings and education before becoming village leaders or from organizations they had joined and actively participated. The majority of village leaders (78\%) stated that they were active in organizations but $22 \%$ of them were not. Thus, it could be preliminary concluded that they have prior knowledge of organizations and leadership.

The leaders also had sufficient understanding of Village Acts covering the local issues and rules that they obtained from education and trainings conducted by Local Government or through media (news,

\footnotetext{
${ }^{14}$ Ibid

${ }^{15}$ Ibid, Page 20
} 
manuals, and others.). The survey showed that of 27 village heads, 17 (63\%) stated that they knew well about the Village Acts, 10 (37\%) stated that they partially knew about the Village Acts. All respondents $(100 \%)$ stated that new competences to face the village Acts were greatly needed since leaders at the level of villages were required to be more responsive, transparent in serving people, and have more creativity and innovation in implementing the Village Acts so that the village development, vision and mission achievement may be reached.

The majority of the respondents (85\%/23 Village leaders) choose transformational leadership style which mainly focuses on community closeness, modeling and motivation to jointly develop the village through innovative and useful works.

The survey results showed that there was no comprehensive understanding from heads of the villages in Ajibarang and Wangon sub-district related to global leadership and its supporting elements. Almost half $(44 \%)$ of the respondents stated that they never knew while the other $56 \%$ stated that they a little knew about AEC. There was no official socialization about AEC from the government. The survey results also showed that the involvement of village leaders in the global interaction was still poor with only $30 \%$ of respondents said that they had involved in global interaction. Even so, it was not a direct interaction but only through intermediaries. Most respondents (70\%) stated that they had never been involved in global interactions. Similarly, when they were asked the factors supporting global interactions such as foreign language skills, $81 \%$ of respondents said that they had no foreign language skills at all. Only $22 \%$ of villages had foreign language skills, but limited to basic communication skills only. The majority $(78 \%)$ said that they had no officials with foreign language skills.

The entire village leaders surveyed (100\%) were aware of the need for global leadership insight and global-minded leaders to improve the society who live in this rapid international developments recently. Good and new strategies needed to face AEC were also stated by the majority respondents $(89 \%)$.

Below are the survey results on global leadership per sub-district of Ajibarang and Wangon in Banyumas district, Central Java:

\subsection{Ajibarang Sub-district}

\subsubsection{The Insights on AEC of 2015 and Village Acts}

Some village leaders had known that the village Acts of 2014 govern the village and its finances containing rules of fund allocation and disbursement for the village, salary distribution to heads and officials of the villages and transparency concerning to financial bookkeeping. They got the information on the Village Acts from the trainings conducted by the local government and manuals that they received.

There had also been socialization from the government on Village Acts. For example Pancurendang village received socialization from the head of section of sub-district officials of Banyumas and the Agency of Regional Development (bappeda). While Jingkakang, Banjarsari, Pandansari, Pancasan, Ciberung, Kracak, East Ajibarang, Kalibenda, South Tipar , Lesmana, Karang Bawang and Darmakradenan village received the socialization from the head of section of the government. West Ajibarang village had the socialization when education and training were conducted by the local government that one of the materials was about Village Acts. Sawangan village had the socialization from head of section of Satria Praja governance of Banyumas.

The preparation of the village leaders on the application of Village Acts were considered poor since these new regulations were at the stage of transition from the old system. Respondents still needed more training, such as training on using technological devices (computers and internet) and bookkeeping. However, in terms of financial management planning, they said that they were adequately prepared. There were many programs that they had planned related to the use/allocation of village funds, for example for infrastructure development (roads, irrigations), as business capital assistance, and others.

\subsubsection{Leadership Styles}

The village leaders chose the transformational leadership style for some reasons. First, because they were elected by the people, so they should directly involve in solving all people's problems. Second, 
they must directly ensure and know the needs of the surrounding people .Third, the village leaders may get closer to people as heads of the village governance was different from others. For example, when the village leaders wanted to hold a village meeting with heads of the neighborhood (RT), who represents the community, the meeting was usually held at night because people were busy with their jobs during the day.

Some village leaders used leadership patterns with the mechanism of rewards to motivate the village officials to work better and be more responsible. This is also aimed to improve the performance of village governance such as conducted by heads of West Ajibarang, Lesmana, and South Tipar village. Hwever, the heads of East Ajibarang, Pandansari, Pancasan, and Ciberung tended not to use reward in their leadership styles as the awareness to develop the village was not by giving presents. Besides, there was no system stating the reward system.

According to the head of Lesmana village, this leadership style was conducted in order that all village officials are effectively empowered. However, the authority was not completely given as head of village still needed to directly interact with the community. Meanwhile, the head of Pancasan village did the same thing because head of village might have delegation instead of his presence. However, head of Ajibarang village chose leadership style which directly interacted with the community.

\subsubsection{Strategies to Develop the Villages}

There were no forms of international interaction before. There is only one village with a cement factory owned by a foreign country. The interaction was indirectly undertaken by an agency. In general, heads of the villages had never interacted globally due to the chances and were constrained by foreign language skills. They did not know whether there was an international vision, mission, and instructions from the government. Most of them were only busy with issues within the scope of the village.

The village leaders were pursuing to develop the economic potential in the village. For example, to continuously improve the quality of their village products and develop the potential, Ciberung village made dages (a kind of local food) as OVOP One Village One Product and keep trying to improve the others. Most other villages were continuously trying to improve the existing potential in their villages by continuously promoting and improving the main productions of their villages, for example Pancasan village with its tile products.

\subsubsection{The Understanding of Global Leadership Insight}

The village leaders understood the need of global insight leadership at the level of village to face the AEC, especially to update the information and global development. Leaders with global insight may give benefit in knowing how the existing potentials in the village might become something that brings progress for the village due to the presence of the AEC.

According to them, leaders without global insight might lead people to difficulties in facing the AEC and be left behind upon the current global developments.

The village leaders were still waiting for the government to create, undertake new strategies, and follow the government instructions or rules at the higher levels. At this time, the strategies they undertook were limited only on the existing working programs in local government regulations but no strategies to face AEC which was just new information.

\subsection{Wangon Sub-district}

\subsubsection{The Insights on AEC of 2015 and Village Acts}

The heads of 12 villages in sub-district Wangon had not known in detail what AEC of 2015 was. They only knew that the AEC was free trades between countries in ASEAN territory. They got the information from news on TV or through printed media. The utilization of Internet technology was still very poor.

Some village leaders had already got the socialization from the government. BUT, the majority of socialization was conducted around their areas of election by the legislative candidates. The 


\section{Dr. Ely Triasih Rahayu S.S., M. Hum et al.}

socialization was unevenly distributed. Some villages had already got the socialization but some others did not get the socialization at all. No village had already received the official socialization from the government.

The village leaders generally knew what the Village Acts were. Village Acts were regulations which gave privileges to govern and manage the village itself, especially in financial terms (including the distribution of salaries and division of bengkok portion) with the main objective on the welfare of the people and communities.

The information were obtained from the socialization conducted by the local government through education and training, manuals distributed during the training, and others (socialization conducted by legislative candidates around their areas of election) held before the election of 2014.

\subsubsection{Leadership Styles}

In general, the village heads had transformational leadership style for some reasons. First, because they were elected by people, they were willing to get closer to people and motivate them to well behave. Second, they are directly involved in people's activities as they wanted to know the existing problems, try to solve them along with the other village officials and formulated them together in the village meeting. Third, they had to build close relationship with the society since their mechanism to be reelected was through direct election. The spirit to develop the village encouraged them to be a good paragon for the society.

Leadership style with reward mechanism was implemented by the head of Klapagading village. According to him, reward might motivate people to well behave. Punishment (penalty) mechanism was not applied. Repair mechanism through advice and input was emphasized more. The delegating leadership style upon decisions was performed by head of Rawaheng village. He sometimes delegated someone with certain criteria (for example: had the capacity, honesty, and well time management) that hopefully that person might actually be trusted in particular cases.

\subsubsection{Strategies to Develop the Village}

Some villages had direct contact with foreign people, such as Klapagading, Randegan, and Wlahar. In Klapagading, foreigners intentionally come to see live cultural performances, such as kuda lumping or frequently called as "Ebeg". In Randegan, there was an educational workshop called "Oemah Bejo". Almost every week foreigners visited it and taught villagers English. In Wlahar, some foreigners from Germany were interested in cooperation to establish liquor factories (ciu). Because it was classified illegal, the cooperation was then closed. Young generations of Wlahar had already had direct contact with internet, either to access national or international information.

The village leaders in Wangon generally had no direct contact before due to the chances and limited foreign language skills. In addition, they found it difficult to use information technology.

Most of them tried to maximize the agricultural potential. Klapagading developed its potential on ant sugar which had already reached the international markets. The village tried to create independent farmers who could produce their own seeds, fertilizers, and even products. Wlahar village also tried to utilize its natural agricultural potential to make its own beverage called ciu. Other villages also tried to utilize its lands for planting trees, such as Windunegara village which developed SMEs of plywood industry and stone crushing. Most villages improved their infrastructure including Randegan village to support the distributions of agricultural products such as ant sugar and dried banana (sale) to the market.

\subsubsection{The Understanding of Global Insight Leadership}

All heads of the villages agreed on the importance of global insight leadership that people might be prepared better to face the AEC. The leaders should know the latest information that they would understand what steps to take to prepare their people and village officials in facing global development. The leaders could anticipate the negative impacts that might be resulted and take the positive ones for the betterment of the village and its people.

Most heads of the villages were waiting for orders/instructions from higher authorities. The majority had no innovation or breakthrough to develop their village. They only focus on developing the village with the existing potentials, without understanding the AEC. The head of Klapagading, who was formerly a businessman in Jakarta, mentioned a different opinion that he was aware upon what might 
Banyumas as a Part of Southeast Asian Maritime World: A Study of the Readiness of the Regency to Deal with the ASEAN Economic Community

happen if AEC was implemented. Thus, he was trying to create independent farmers who could produce their own seeds, fertilizers and even products by themselves.

\subsubsection{The Preparation upon the Implementation of Village Acts}

With the privilege of Village Acts, most villages were ready to make their working programs to build and improve their insufficient infrastructure to support their people. Moreover, with more sophisticated system, the financial violations might be reduced. Villages with less competence leaders and people would be provided with training or courses to create their independence.

\section{CONCLuSion}

The efforts to prepare our nation to face the ASEAN Economic Community that came into effect in 2015 should be undertaken at all levels of society. The government is certainly the fore guard of people to face ASEAN free trades. The preparation should not only be undertaken at the government level as the policy makers, but also at regional and village levels.

National leadership at village level is the closest sites on various problems and challenges faced by the society whether at the level of regional, national or even international. Free trade makes everything borderless. Therefore, global insight leadership starting at the regional to the village level is greatly required.

This study shows that village governance is not ready to face the ASEAN Economic Community of 2015. The village leaders have already owned a better prior understanding on leadership and organization auto-didactically or from organizations that they actively joined before. Thus, the policy formulations which support the official preparation at any levels of governance, especially at village level which is directly in contact with the public should be undertaken immediately. Global Leadership Model is a part of the preparation efforts to face global challenges that government officials are expected to be responsive, innovative, effective and efficient in responding the local and global developments.

\section{REFERENCES}

\section{BOOKS}

Badan Pusat Statistik (BPS),2013. Kabupaten Banyumas dalam Angka. Biro Pusat Statisik Kabupaten Banyumas

Badan Pusat Statistik (BPS),2012. Kabupaten Banyumas dalam Angka. Biro Pusat Statisik Kabupaten Banyumas

Badan Pusat Statistik (BPS),2011. Kabupaten Banyumas dalam Angka. Biro Pusat Statisik Kabupaten Banyumas

Mas'oed, Mohtar, 1989. Studi Hubungan Internasional: Tingkat Analisisi dan Teorisasi, PAU Studi Sosial UGM.Yogyakarta.

McKinsey, A.\& Company, 23 Januari 2007.An ASEAN Economic Community by 2015.Dipublikasikan oleh ASEAN Secretariat. Jakarta

Miles, M.B., and Huberman A.M., 1984.Qualitative Data Analysis.Saga Publication. California

Moleong, Lexy, 2007.Metode Penelitian Kualitatif. PT Remaja Rosdakarya. Bandung

Pangestu, Mari Elka dkk (penyunting), 2003.75 Tahun Suhadi Mangkusuwondo : Indonesia dan Tantangan Ekonomi Global. Centre for Strategic and International Studies(CSIS). Jakarta.

Santoso, Purwo dkk (Editor), 2004. Menembus Ortodoksi Kajian Kebijakan Publik. FISIPOL UGM. Yogyakarta.

Wirawan. 2013. Kepemimpinan : Teori, Psikologi, Perilaku Organisasi, Aplikasi dan Penelitian. PT. RajaGrafindo Persada. Jakarta

\section{JOURNALS AND RESEARCHES}

ASEAN Secretariat, 2008.ASEAN Economic Community Blueprint

ASEAN Secretariat, 2009.Implememnting Road Map of ASEAN

ASEAN Secretariat, 2010.ASEAN Economic Community Scorecard."Charting Progress Towards Regional Economic Integration”. Publikasi ASEAN Secretariat. Jakarta 
ASEAN Secretariat, 2012.Investing in ASEAN 2012.Allurant United

Bank Indonesia, 2008, Outlook Ekonomi Indonesia 2008-2012."Integrasi Ekonomi ASEAN dan Prospek Perekonomian Nasional". Edisi Januari 2008. Biro Riset Ekonomi - Direktorat Riset Ekonomi dan Kebijakan Moneter Bank Indonesia. Jakarta

BPMP Kabupaten Banyumas, 2011, Banyumas: Trading \& Investment. Badan Penanaman Modal dan Pelayanan Perizinan (BPMPP) Kabupaten Banyumas

BPMP Kabupaten Banyumas, 2011, Menelusuri Peluang Potensi dan Investasi Kabupaten Banyumas.Badan Penanaman Modal dan Pelayanan Perizinan (BPMPP) Kabupaten Banyumas

Cuyvers, Ludo dan Wisarn Pupphavesa, 1996. From ASEAN to AFTA.CAS Discussion Paper No.6. September 1996. Centre for ASEAN Studies - Centre for International Management and Development Antwerp

Handayani, Agustuti, 2010. "Analisis Pengaruh Gaya Kepemimpinan dan Motivasi Kerja terhadap Kinerja Pegawai pada Dinas Tenaga Kerja Propinsi Lampung”.Jurnal Ilmiah Administrasi Publik Dan Pembangunan, Vol.1, No.1, Januari - Juni 2010.

Institute for Global Justice, ASEAN Watch,Volume I, No.3, March 2009.“FTA Trapping to Practice Market Liberalization". Institute for Global Justice

Jurnal Media Keuangan, 2012. "KemajuanEkonomi, Peluang Investasi”. Volume VII No.53 Januari 2012

Miryanti, Renny dkk, 2013.Model Masyarakat Ramah Investasi untuk Mendukung Kesiapan Kabupaten BanyumasMenghadapi Free Flow of Investment ASEAN Economic Community 2015. Lembaga Penelitian dan Pengabdian Kepada Masyarakat Universitas Jenderal Soedirman. Purwokerto

Miryanti, Renny, 2011. "Peluang dan Tantangan dalam Membangun Masyarakat ASEAN 2015: Menengok ASEAN dan Uni Eropa", Jurnal Insignia, Vol.1. No.1.Tahun 2011

Puspitasari, Intan dkk. 2014."Analisis Gaya Kepemimpinan Lintas Budaya Ekspatriat (Studi Penelitian Pada PT. Haier SalesIndonesia, Jakarta Utara)”. Jurnal Administrasi Bisnis (JAB) Vol. 8 No. 1 Februari 2014. Universitas Brawijaya.

Saraswati, Veronika, 2009. “ASEAN: Bentuk Regionalisme atau Perpanjangan Empire?”.Global Justice Update, Tahun ke-6, Edisi 1, Maret 2009. Institute for Global Justice

Soegihartono, A.,2012. "Pengaruh Kepemimpinan dan Kepuasan Kerja terhadap Kinerja dengan Mediasi Komitmen (di PT Alam Kayu Sakti Semarang)".Jurnal Mitra Ekonomi dan Manajemen Bisnis, Vol.3, No. 1, April 2012

Soesastro, Hadi, 2004. Kebijakan Persaingan, Daya Saing, Liberalisasi, Globalisasi, Regionalisasi, dan Semua Itu, CSIS Working Paper Series Maret 2004.

Citation: Dr. Ely Triasih Rahayu, S.S., M. Hum, Renny Miryanti, S.IP., M.Si, Tundjung Linggarwati, S.IP., M.Si, "Banyumas as a Part of Southeast Asian Maritime World: A Study of the Readiness of the Regency to Deal with the ASEAN Economic Community", International Journal of Humanities Social Sciences and Education (IJHSSE), vol. 4, no. 8, pp. 65-74, 2017. http://dx.doi.org/10.20431/2349-0381.0408009

Copyright: (๑) 2017 Authors. This is an open-access article distributed under the terms of the Creative Commons Attribution License, which permits unrestricted use, distribution, and reproduction in any medium, provided the original author and source are credited. 